\title{
Pengaruh Sikap, Norma Sosial, Persepsi Perilaku terhadap Intensi Penggunaan Narkoba di Kalangan Remaja
}

\author{
Ikhsan Fuady $^{1 *}$, Ditha Prasanti ${ }^{2,}$ Nurhayati $^{3}$ \\ ${ }^{1,2,}$ Fakultas Ilmu Komunikasi, Universitas Padjadjaran, Jatinangor, 45363, Indonesia \\ ${ }^{3,}$ Balai Besar Pengkajian dan Pengembangan Teknologi Pertanian Bogor, Indonesia \\ *email: ikhsan.fuady@unpad.ac.id
}

\begin{abstract}
Abstrak
Permasalahan penyalahgunaan narkoba di kalangan remaja menjadi permasalahan yang serius. Permasahan ini memiliki dampak terhadap masa depan generasi muda kedepan. Penelitian ini bertujuan untuk menganalisis faktor-faktor yang mempengaruhi intensi atau niat remaja dalam berperilaku penyalahgunaan narkoba. Metode penelitian ini dengan menggunakan metode kuantitatif dengan pendekatan survey. Sampel penelitian ini adalah kalangan remaja yang tinggal di salah satu Kabupaen di Jawa Barat. Uji analisis pada penelitian ini adalah dengan mengunakan uji regresi linier berganda dengan metode backward. Berdasarkan hasil penelitian diketahui bahwa intensi perilaku remaja dalam penyalahgunaan narkoba terkategori sedang. Adapu faktor-faktor yang mempengaruhi intensi perilaku polah hidup sehat adalah faktor sikap remaja terhadap narkoba itu sendiri dan persepsi perilaku remaja.
\end{abstract}

Kata kunci: Intensi, perilaku, sikap

\begin{abstract}
The problem of drug abuse among adolescents becomes a serious problem. This problem has an impact on the future of the young generation in the future. This study aims to analyze the factors that influence the intentions or intentions of adolescents in drug abuse behavior. This research method uses quantitative methods with a survey approach. The sample of this study was among adolescents living in one of the regencies in West Java. Test analysis in this study is to use multiple linear regression test with the backward method. Based on the results of the study note that the intentions of adolescent behavior in moderate category of drug abuse. Adapu factors that influence the intention of healthy lifestyle behavior are factors in adolescent attitudes towards drugs themselves and perceptions of adolescent behavior.
\end{abstract}

Keywords: Intention, behavior, attitude

\section{Pendahuluan}

Narkotika dari asal kata diambil dari bahasa Yunani yaitu "narke" yang bermakna terbius yang menyebabkan tidak dapat merasakan apa-apa. Sebagian orang berpendapat bahwa narkotika berasal dari kata "narcissus" yang berarti sejenis tumbuhan tumbuhan yang mempunyai hubungan yang dapat menyebabkan orang menjadi tidak sadarkan diri. WHO mendefinisikan narkoba ini sebagai segala suatu zat yang apabila 
dimasukkan ke dalam tubuh akan mempengaruhi fungsi fisik dan atau psikologi (kecuali makanan, air, atau oksigen). Narkoba (nakoba dan Obat/Bahan Berbahaya), disebut juga NAPZA (Narkotika, Psikotropika dan Zat Adiktif lain) adalah obat bahan atau zat bukan makanan yang jika diminum, diisap, dihirup, ditelan, atau disuntikan, akan memiliki dampak terhadap otak jika zat tersebut masuk ke tubuh manusia sehingga menyebabkan permasalahan seperti terjadinya gangguan pada fisik, psikis, atau juga fungsi sosialnya karena terjadi kebiasaan, ketagihan (adiksi) serta ketergantungan (dependensi) terhadap NAPZA tersebut. Berdasarkanragam atau varian narkoba dapat menyebabkan; perubahan pada suasana hati, perubahan pada pikiran dan perubahan perilaku.

Penyalahgunaan narkoba di Indonesia dari waktu kewaktu, semakin meningkat dan permasalahan yang ditimbulkan juga semakin kompleks. Kriminalitas di bidang narkoba merupakan kejahatan lintas negara (transnational crime), terorganisir (organized crime), dan serius (serious crime) yang dapa mampu menimpa berbagai lapisan masyarakat, baik kelas atas maupun bawah, baik kalangan tua maupun muda. Masalah penyalahgunaan narkoba di kalangan remaja dan pelajar dapat dikatakan sulit di atasi, karena penyelesaiannya melibatkan banyak faktor dan kerjasama dari semua pihak yang bersangkutan, seperti pemerintah, aparat, masyarakat, media massa, keluarga, remaja itu sendiri. Penyalahgunaan narkoba terjadi karena korban kurang atau tidak memahami apa narkoba itu sehingga dapat dibohongi oleh pihak yang tidak bertanggung jawab (pengedar).

Peredaran narkoba di kalangan remaja semakin hari semakin memperihatinkan. Prevelensi berda pada angka 4,7 persen pengguna narkoba adalah pelajar dan mahasiswa. Badan Narkotika Nasional (BNN) mengakui pengaruh narkoba telah merambah ke berbagai kalangan. Berdasarkan survei BNN, penggunaan narkoba tercatat sebanyak 921.695 orang adalah pelajar dan mahasiswa (Anonim 2019).

Semakin meningkatnya permasalahan permasalahan penyalahgunaan narkoba dikalangan remaja, tidak lepas dari sikap dan dan intensi perilaku remaja itu sendiri. Berdasarkan permasalahan di atas, bagaimana sikap dan intensi perilaku pola perilaku sehat masyarakat, serta faktor faktor yang mempengaruhinya merupakan suatu hal yang menarik dikaji.

Dalam menjelaskan perubahan perilaku, model yang sering digunakan dalam menganalisis dari perspektif psikologi adalah menerapkan Theory of Planned Behavior (TPB). Kerangka teori yang digunakan pada penelitian ini adalah dengan menggunakan konsep dalam komunikasi lingkungan serta Theory of Planned Behavior (TPB). Banyak studi saat ini yang menerapkan Theory of Planned Behavior (TPB) untuk memprediksi niat perilaku tertentu. Sebuah tinjauan literatur menemukan beberapa penelitian sebelumnya tentang niat perilaku (Chan, 1998); perilaku penghematan listrik (Wang et al., 2011); perilaku penghematan energi (Wang et al., 2015); peralatan efficient energi (Yen et al., 2017)telah menerapkan Theory of Planned Behavior (TPB) mendukung model mereka. Apalagi banyak penelitian internasional baru-baru ini dilakukan tentang isu isu kesehatan dan lingkungan telah menggunakan TPB sebagai landasan kerangka teoretis (Albayrak et al., 2013; Klockner, 2013; Millock dan Nauges, 2010). Banyak peneliti selain yang diidentifikasi faktor yang mempengaruhiintensi dengan menerapkan TPB diperluas sebagai dasar teoritis untuk mempelajari apakah konsumen berniat melakukan perilaku tertentu (misalnya Alam et al., 2014; Chan dan Bishop, 2013; Chen dan Tung, 2014; Greaves el al, 2013; López-Mosquera dkk., 2014; Mi et al., 2011). Berdasarkan studi literatur ini, dalam konteks intensi dalam perilaku penyalahgunaan 
narkoba peneliti mencoba menganalisis faktor-faktor apa yang mempengaruhinya intensi masyarakat dalam perilaku penyalahgunaan narkoba di kalangan remaja.

\section{Metode Penelitian}

Penelitian didesain sebagai penelitian kuantitatif dengan metode survey. Berdasarkan tujuan umum penelitian, peneliti berusaha mengetahui faktor faktor yang mempengaruhi intensi individu pola perilaku penyalahgunaan narkoba. Untuk mencapai tujuan tersebut peneliti mendesain penelitian yang bersifat menerangkan (explanatory research). Menurut Babbie (1992) penelitian bersifat menerangkan adalah penelitian survey yang bertujuan menjelaskan pengaruh dan hubungan antar peubah melalui pengujian hipotesis.

Metode survey digunakan untuk pengumpulan data dari seluruh anggota populasi. Ciri khas pengumpulan data melalui survey adalah data dikumpulkan dari sejumlah responden dengan menggunakan kuesioner. Keuntungan utama dari survey adalah dimungkinkannya membuat generalisasi untuk populasi berdasarkan analisa terhadap sampel yang berasal dari populasi tersebut.

Penelitian dilaksanakan di beberapa SMA pada Kabupaten X di Propinsi Jawa Barat. Dalam menjaga etika penelitian, peneliti me"anonim"kan lokasi penelitian dan objek penelitian. Babbie (1992) berpendapat ada lima etika dalam penelitian yang harus dihormati oleh setiap peneliti: (a) Peneliti tidak dapat memaksa seseorang untuk ikut serta dalam suatu penelitian. (b) Peneliti tidak boleh memberikan keterangan yang keliru untuk mendorong subyek agar mau ikut serta dalam suatu penelitian. (c) Tidak boleh membawa cedera (fisik maupun psikologis) bagi para subyek penelitian: subyek penelitian adalah anonim (tidak dikenal) dan confidential (rahasia). (d) Peneliti dituntut untuk menyajikan data penelitian secara jujur. (e) Hipotesis harus dibuat sebelum penelitian diawali, bukan setelah hasil penelitian diketahui.

Waktu pelaksanaan penelitian dilakukan survey pada Bulan Februari 2019. Populasi penelitian ini adalah remaja. Menurut Papalia \& Olds (2008), masa remaja adalah masa transisi perkembangan antara masa kanak-kanak dan dewasa yang pada umumnya dimulai pada usia 12 atau 13 tahun dan berakhir pada usia akhir belasan tahun atau awal dua puluhan tahun. Sampel penelitian ini adalah sebagaian dari populasi yang diambil secara insidental sampling sebanyak 45 responden.

\section{Pembahasan}

Permasalahan penyalahgunaan narkoba dikalangan remaja merupakan permasalahan yang yang penting untuk diselesaikan karena Muchlis (dalam Tempo, 2004) 70 persen dari 4 juta pecandu narkoba tercatat sebagai anak usia sekolah, yakni berusia 14 hingga 21 tahun, bahkan sudah menyusup ke anak usia SD. Semakin meingkatnya niat atau intensi penyalahgunaan narkoba ini tidak lepas dari banyak faktor baik dalam individu maupun faktor sosial.

Pada dasarnya, remaja merupakan individu yang memiliki rasa keingintahuan yang tinggi terhadap sesuatu. Pemahaman dan pengetahuan serta bimbingan orang tua yang kurang tentang bahayanya narkoba dapat menjebak remaja pada jeratan narkoba. Kondisi ini diperparah dengan masifnya para pengedar narkoba masuk kesekolah 
sekolah. Pergaulan bebas dan interkasi dalam sosial media, memperburuk kondisi untuk remaja terjerat dalam lingkaran narkoba.

Berdasarkan hasil analisis dari responden yang diteliti, sebagaian remaja pernah melihat dan mengkonsumsi narkoba. Secara umum intensi untuk pengguna narkoba yang terkategori sangat rendah dan rendah adalah 80 persen sedangkan terkategori sedang sebanyak 17,80 persen. Persentase keinginan atau intensi remaja dalam penggunaan narkoba digambarkan pada Tabel 1 berikut.

Tabel 1. Persentase Intensi Remaja dalam Penggunaan Narkoba

\begin{tabular}{lll}
\hline No & \multicolumn{1}{c}{ Intesi } & Persentase $\mathbf{( \% )}$ \\
\hline 1 & Tinggi & 0,00 \\
\hline 2 & Sedang & 17,80 \\
\hline 3 & Rendah & 35,60 \\
\hline 4 & Sangat rendah & 46,70 \\
\hline & Total & 100,00 \\
\hline
\end{tabular}

Sumber: analisis data primer

Untuk perilaku remaja terhadap aksesibilitas narkoba, dapat digambarkan pada Tabel 2 di bawah ini. Sebanyak 13,3 persen remaja pernah melihat salah satu dari varian narkoba. Sedangkan tingkat penggunaan, sebanyak 6,7 persen remaja pernah mencoba dari ragam narkoba tersebut.

Tabel 2. Perilaku Remaja terhadap Aksesibilitas Narkoba

\begin{tabular}{c|c|c|c}
\hline \multicolumn{3}{c}{ Perilaku } \\
\hline \multicolumn{2}{c}{ Melihat } & \multicolumn{2}{c}{ Menggunakan } \\
\hline Pernah & Tidak Pernah & Pernah & Tidak Pernah \\
\hline $13,3 \%$ & $86,7 \%$ & $6,7 \%$ & $93,3 \%$ \\
\hline
\end{tabular}

Sumber: analisis data primer.

Berdasarkan tabel di atas, meunjukan prevelensi penggunan narkoba dikalangan remaja relatif sedikit di atas prevelensi nasional sebesar 6,7 persen pernah menggunakan narkoba. Kondisi ini dapat menggambarkan perkembangan peredaran narkoba bersifat progresif.

\section{Faktor Faktor yang Mempengaruhi Intensi Remaja dalam Perilaku Penyalahgunaan Narkoba}

Perilaku remaja dalam penyalahgunaan narkoba sangat dipengaruhi oleh banyak faktor, baik internal maupun eksternal. Kondisi psikologi, lingkungan luar, literasi informasi, dan beragam faktor lainnya secara teoritis memiliki kontribusi terhdap perilaku individu. Pada penelitian ini, peneliti menggunakan teori perilaku berencana sebagai kerangka teoritis, dimana faktor yang mempengaruhi intensi perilaku individu adalah aspek sikap individu terhadap narkoba, lingkungan sosial atau sosial norm, sertaa persepsi individu terhadap perilaku atau pandangan terhadap kemampuan individu untuk melakukan perilaku.

Hipotesis penelitian ini adalah, diduga faktor sikap, norma subjektif (social norm), dan persepsi terhadap perilaku penggunaan narkoba memiliki pengaruh terhadap intensi atau niat individu dalam melakukan perilaku penggunaan narkoba dikalangan remaja. Sikap adalah kondisi mental dan neural yang diperoleh dari pengalaman, yang 
mengarahkan dan secara dinamis mpengaruhi respon-respon individu terhadap semua objek dan situasi yang terkait. c). Norma subyektif berhubungan dengan pandangan seseorang terhadap suatu keadaan atau kejadian, dan perasaan yang timbul apabila seseorang tidak mengikuti pandangan orang lain atas suatu keadaan atau kejadian. Norma subjektif adalah persepsi seseorang mengenai tekanan sosial untuk melakukan atau tidak melakukan perilaku (Ajzen,1991). Kontrol perilaku yang dirasakan mengacu pada persepsi orang tentang kemudahan atau kesulitan melakukan perilaku yang diminati. Peranan kontrol perilaku memainkan peran penting dalam teori perilaku terencana dan merupakan variabel penyempurnaan dari teori tindakan beralasan.

Berdasarkan hasil analisis dengan mengunakan uji regresi linier berganda metode backward dengan SPSS 20 for windows diketahui faktor yang mempengaruhi intensi masyarakat dalam berperilaku pola hidup sehat digambarkan pada tabel di bawah ini.

Tabel 3. Uji Regresi Linier

\begin{tabular}{|c|c|c|c|c|c|c|}
\hline \multicolumn{7}{|c|}{ Coefficients $^{\mathrm{a}}$} \\
\hline & & \multicolumn{2}{|c|}{$\begin{array}{l}\text { Unstandardized } \\
\text { Coefficients }\end{array}$} & \multirow{2}{*}{$\begin{array}{c}\begin{array}{c}\text { Standardized } \\
\text { Coefficients }\end{array} \\
\text { Beta }\end{array}$} & \multirow[b]{2}{*}{$\mathbf{T}$} & \multirow[b]{2}{*}{ Sig. } \\
\hline \multicolumn{2}{|c|}{ Model } & B & Std. Error & & & \\
\hline \multirow[t]{4}{*}{1} & (Constant) & -.783 & 2.288 & & -.342 & .734 \\
\hline & $\mathrm{pbc}$ & .672 & .238 & .352 & 2.823 & .007 \\
\hline & sn & .020 & .113 & .024 & .179 & .858 \\
\hline & att & .476 & .064 & .655 & 7.486 & .000 \\
\hline
\end{tabular}

a. Dependent Variable: int

Sumber : Analisis data primer.

Berdasarkan hasil analisis data, diketahui faktor-faktor yang mempengaruhi intensi masyakat dalam pola hidup sehat adalah variabel sikap masyarakat dan variabel social norm. Berdasarkan hasil analisis di atas, maka dapat di bangun persamaan faktor faktor yang mempengaruhi intensi masyarakat sebagai berikut;

Dimana:

$$
Y=-0,78+0,47 X_{1}+0,67 X_{3}+e
$$

$\mathrm{Y}:$ Intensi remaja

$\mathrm{X}_{1}$ : Sikap

$\mathrm{X}_{3}$ : Persepsi terhadap perilaku

Perilaku penyalahgunaan narkoba dikalangan remaja akhir akhir ini sangat mengkhawatirkan. Berdasarkan hasil analisis dengan menggunakan uji regresi linier berganda, secara umum perilaku penyalahgunaan narkoba ini sangat dipengaruhi oleh aspek sikap remaja dan juga persepsi remaja terhadap kemampuan melakukan perilaku tersebut. Sementara intensi remaja tidak secara nyata dipengaruhi oleh social norm. 
1. Pengaruh sikap terhadap intensi penggunaan narkoba

Dalam teori tindakan berencana, menyatakan bahwa sikap individu terhadap suatu objek memiliki pengaruh yang positif terhadap intensi individu dalam berperilaku. Sikap yang dapat mendorong seseorang berperilaku antara lain adalah sikap yang kuat, semakin kuat sikap maka cenderung untuk berperilaku sebagaimana sikapnya. Berdasarkan hasil analisis, diketahui intensi remaja dalam dalam penyalahgunaan narkoba dipengaruhi cukup kuat oleh sikap remaja tentang narkoba itu sendiri. Sikap terhadap penggunaan narkoba didefinisikan sebagai pandangan ataupun keyakinan individu terhadapmanfaat yang dirasakan oleh remaja. Pengaruh sikap terhadap intensi ini digambarkan dengan koefisien pengaruh sebesar 0,67, dengan nilai signifikasi 0.000 lebih kecil dari tingkat kesalahan alfa 1 persen atau dengan kata lain nilai $t_{\text {hitung }}>t_{\text {tabel }}$. Berdasarkan hasil analisis data, model pengaruh sikap terhadap intensi dapat digambarkan pada bersamaan berikut;

$$
\mathrm{Y}=-0,78+0,47 \mathrm{X}_{1}+\mathrm{e}
$$

Dimana $\mathrm{Y}$ : intensi remaja dalam penyalahgunaan narkoba $\mathrm{X}_{1}$ : sikap remaja terhadap narkoba

Berdasarkan persamaan di atas, peningkatan satu satuan sikap dapat meningkatkan intensi remaja sebesar 0,47 satuan. Sikap remaja memiliki pengaruh yang sangat erat dengan keinginan atau intensi remaja dalam penyalahgunaan narkoba. Sikap remaja yang cenderung positif atau meyakini manfaat atau dampak dari penggunaan narkoba menyebabkan semakin menguatnya keinginan mereka untuk memakai atau penyalahgunaan narkoba. Sementara itu keyakinan atau pandangan remaja yang memamdang buruk akibat penyalahgunaan narkoba semakin besar keinginan menghidari dari mengkonsumsi barang haram ini.

Pembentukan sikap atau keyakinan remaja ini sangat tergantung pada beragam informasi yang dimiliki remaja dari bebrbagai sumber. Pergaulan yang salah dan kurangnya edukasi tentang bahaya penyalahgunaan narkoba berdampak pada konstruksi atau pembentukan sikap tentang narkoba yang tidak tepat. hal ini didukung oleh penelitian (Arifin, Fuady, \& Kuswarno, 2017) mengungkapkan bahwa keyakinan dn persepsi individu sangat dipengaruhi oleh faktor ekternal ataupun faktor lingkungan.

Berdasarkan hasil analisis ini, diperlukan suatu edukasi atau pendampingan bagi remaja untuk memberikan pemahaman yang tepat tentang dampak yang sangat buruk akibat dari penyalahgunaan narkoba. Selain itu melakukan pengontrolan terhadap pergaulan remaja menjadi suatu hal yang penting, untuk menghindari dari salahnya pergaulan remaja dengan orang lain yang bisa menjerumuskan remaja kedalam perangkap penyalahgunaan narkoba.

\section{Pengaruh perceive behavior control terhadap intensi penyalahgunaan narkoba}

Perceive behavior control berhubungan dengan pandangan atau persepsi seseorang terhadap perilaku tertentu. Perceive behavior control remaja adalah persepsi remaja mengenai tindakan atau perilaku untuk menggunakan narkoba (Ajzen,1991). Dalam model theory of reasoned action dan theory of planned behavior, Perceive behavior control adalah fungsi dari kemampuan remaja untuk melakukan tidakan tersebut. Perceive behavior control banyak dikaji pada penelitianpenelitian psikologi, seperti penelitian tentang intensi berwirausaha (Andika dan 
Iskandarsyah, 2012) menunjukkan Perceive behavior control memiliki pengaruh terhadap intensi berwirausaha mahasiswa. Norma sosial diperoleh dari mendenganrkan saran orang-orang terdekat.

Berdasarkan hasil analisis, diketahui intensi masyarakat dalam perilaku hidup sehat dipengaruhi cukup kuat oleh norma subjektif masyarakat itu sendiri, dengan koefisien pengaruh sebesar 0,67, dengan nilai signifikasi 0.007 lebih kecil dari tingkat kesalahan alfa satu persen atau dengan kata lain nilai $t_{\text {hitung }}>t_{\text {tabel }}$. Berdasarkan hasil analisis data, model pengaruh sikap terhadap intensi dapat digambarkan pada bersamaan berikut;

$$
\mathrm{Y}=\mathrm{Y}=-0,78+0,67 \mathrm{X}_{3}+\mathrm{e}
$$

Dimana $\mathrm{Y}$ : intensi remaja dalam penyalahgunaan narkoba $\mathrm{X}_{1}$ : Perceive behavior control

Berdasarkan hasil analisis di atas, peningkatan satu satuan perceive behavior control dapat meningkatkan intensi remaja dalam penyalahgunaan narkoba 0,67 satuan. Perceive behavior control remaja sangat erat kaitannya dengan intensi remaja dalam penyalahgunaan narkoba. Persepsi remaja yang tinggi untuk dapat penyalahgunaan narkoba akan cenderung menguatkan individu untuk melakukan perilaku penyalahgunaan narkoba.

\section{Kesimpulan}

Penyalahgunanan narkoba dikalangan remaja sudah sangat mengkhawatirkan. Prevelensi yang semakin meningkat seiring waktu, menyebabkan kekhawatiran banyak pihak. Banyak faktor yang menjadi penyebab meningkatnya intensi remaja dalam penyalahgunaan narkoba. Berdasarkan hasil penelitian diketahui bahwa (1) sikap remaja terhadap narkoba memiliki pengaruh yang kuat terhadap keinginan melakukan penyalahgunaan narkoba. Sikap remaja sangat dipengaruhi oleh beragam infomasi yang membangun persepsi dan keyakinan remaja. Kesalahan pergaulan dan interaksi dapat menyebabkan remaja memiliki sikap yang salah terhadap penyalahgunanan narkoba, dan (2) perceive behavior control atau persepsi remaja untuk melakukan tindakan. Persepsi remaja yang tinggi untuk dapat penyalahgunaan narkoba akan cenderung menguatkan individu untuk melakukan perilaku penyalahgunaan narkoba. Berdasarkan kesimpulan di atas, pencegahanpenyalahgunaan narkoba dapat dilakukan dengan membangun sikap atau keyakinan remaja yang tepat tentang dampak yang diakibatkan dari penyalahgunaan narkoba. Penyuluhan, edukasi ataupun pendampingan merupakan suatu usaha yang baik untuk memberikan pemahaman sikap dan perilaku remaja untuk menghindari dari jeratan narkoba.

\section{Referensi}

Ajzen, Icek (1991). "The theory of planned behavior". Organizational Behavior and Human Decision Processes. 50 (2): 179-211

Albayrak, T., Aksoy, S., \& Caber, M. (2013). The effect of environmental concern and skepticism on green purchase behavior. Marketing Intelligence and Planning, 31 (1), $27-39$.

Andika Manda \& Iskandarsyah Madjid. (2012). "Analisis Pengaruh Sikap, Norma Subyektif dan Efikasi Diri terhadap Intensi Berwirausaha pada Mahasiswa 
Fakultas Ekonomi Universitas Syiah Kuala (Studi Pada Mahasiswa Fakutas Ekonomi Universitas Syiah Kuala). Eco-Entrepreneurship Seminar \& Call for Paper. 190-197

Arifin, H. S., Fuady, I., \& Kuswarno, E. (2017). Analisis Faktor yang Mempengaruhi Persepsi Mahasiswa terhadap Keberadaan Perda Syariah di Kota Serang. Jurnal Penelitian Komonikasi Dan Opini Publik, 21(1), 88-101.

Babbie Earl, 1992. The Practice Of Social Research. California: Wadsworth Publishing Company.

Klöckner, C. A. (2013). A Comprehensive Model of the Psychology of Environmental Behaviour-A MetaAnalysis. Global Environmental Change, 23(5), 1028-1038.

Papalia, D.E., Old, S.W., \& Feldman, R.D. (2008). Human Development (Psikologi Perkembangan). Jakarta: Kencana Predana Media Grup

Yen, Y., Wang, Z., Shi, Y., Xu, F., Soeung, B., Tayyab, M., ... Abdalla, S. (2017). The predictors of the behavioral intention to the use of urban green spaces: The perspectives of young residents in Phnom Penh, Cambodia. Habitat International, 64, 98-108. https://doi.org/10.1016/j.habitatint.2017.04.009

Website:

Anonim. 2019. Penggunaan Narkotika di Kalangan Remaja Meningkat. https://bnn.go.id/penggunaan-narkotika-kalangan-remaja-meningkat/. Diakses 27 november 2019 